\title{
The social-humanitarian disciplines in the technical university: for and against
}

\author{
Nadezda Miloradova ${ }^{1}$, and Alexander Ishkov ${ }^{1, *}$ \\ ${ }^{1}$ Moscow State University of Civil Engineering, Yaroslavskoe shosse, 26, Moscow, 129337, Russia
}

\begin{abstract}
The article discusses the results of social research conducted with the students and the teachers of Moscow State University of Civil Engineering (MGSU). The contradictions between the opinions of University graduates and the teachers of technical and of socialhumanitarian disciplines were discussed. The identified problems lie in the fact that the opinions about the level of socio-humanitarian training of students in the field of "Civil Engineering" are not agreed upon so far, the priorities in the content of socio-humanitarian disciplines (universal or practice-oriented) are not consistent as well.
\end{abstract}

\section{Introduction}

It has been over thirty years since, when the European community adopted the decision on creation of unified educational space (1984). The aim is to increase the mobility of human capital on the European labor market. Throughout the twentieth century many countries have analyzed the higher education system. It was concluded: the higher education system does not meet the requirements of the society and the state, professional communities and individuals. It was therefore decided to develop a new approach. The competent approach has become the basis for the creation of a unified educational space.

The different approaches were developed in the educational theory and the teaching practice, but preference was given to the Competent approach. In this direction the following has been done: the key concepts (competence, competency), the structure and backbone elements of competence were identified and agreed. [1-7]. Four models of competence: the model of personal characteristics, the standard model (algorithmization) procedures and the operations, the management model activity, model the end result, were proposed for the higher professional education [8-10]. Preference was given to models of the end result, which focuses primarily on the ability to learn on your own.

But there were a number of serious problems, not allowing the Competent approach to immediately implement in the educational process, so the research (psychological, pedagogical, methodical) in this direction were recognized as a priority [11-17].

The education system is one of the most conservative areas. The decision about a fundamental transformation this system had been a major step. This decision required a restructuring of the whole educational process: the development of new curricula and courses, methodical processing of all training material. All elements of the education

* Corresponding author: aishkov@gmail.com 
system: goals, content, technologies and organizational forms have undergone changes. The new approach opened up great opportunities for the employers to influence the training of specialists. They expressed serious dissatisfaction with the level of professional training of graduates. And, of course, a serious problem was the training and retraining of teachers. It is not surprising that for the development of the new approach was given twenty-five years.

On the one hand, all countries that have signed the Bologna agreement, were working in the same direction. On the other hand, each country must take into account its own characteristics. Russia signed an agreement in 2003. The decision was made to slow, gradual transition. It was a time of major political and economic transformations in the country. One of the most serious problems is the complete replacement of sociohumanitarian disciplines, because they have the pronounced ideological character. The problem of incorporating non-technical disciplines in the technical universities were interested not only representatives of Russian universities. The European higher education have been presented the results of studies international program (EUCEET, direction SP4) at the conference on building (Paris, 2005). The purpose of this program was to develop recommendations for needs in non-technical subjects that complement the engineering and construction education (CE). However, the inclusion of training courses in sociohumanities in the technical universities still causes tension in the educational environment $[18,19]$. The topic is not closed, remain unresolved a number of serious problems. Among them we can distinguish three fundamentally important issue. Firstly, what students and teachers of the technical University think about the social and humanitarian disciplines? These disciplines also needed to be considered as a special (technical) subjects or these disciplines are not optional for the study.

Secondly, what are the requirements to results of education the socio-humanitarian disciplines? It is known that requirements for the level of development of various competencies are different. The first group of competences is the knowledge that must be learned completely, reaching a level of ability and skills. The second group of competences is formed at the level of understanding the global and impotent problems. The third group of competencies is formed only at the level of general ideas, dating and recognition of major theories, concepts, ideas and ways of working. The socio-humanitarian disciplines should examine the first, second or third level?

- the ontological level: representation, understanding, awareness, reproduction,

- the behavioral level: the application of theories to solve standard (typical) task,

- the existential level: values, meanings, positions.

Thirdly, what should be the priority in the content of socio-humanitarian disciplines? These disciplines remain subject-specific or they should be oriented to the students' profession [20-21]?

To search of answers to these questions defined the goals and objectives of the study. The purpose of this study was to identify the student's and teacher's attitude to the sociohumanitarian disciplines; their expectations on the content and outcomes of education in socio-humanitarian sphere.

The purposes of the research are:

1. To identify and to describe the attitude to the social-humanitarian disciplines of the graduates and the professors from the technical University.

2. To conduct the comparative analysis of the views of the leading professors of the technical and the socio-humanitarian disciplines.

\section{Research methodology}

To conduct the study developed a questionnaire "Social disciplines in a technical University" in three versions. The questionnaire contained direct questions requiring a 
definite answer ("yes" or "no"); open questions, the answers to which required argument. The respondents also expressed their expectations and concerns, offered specific recommendations.

The study was conducted in civil engineering in 2015-2016.

The study involved:

- Twenty five leading professors (19 women and 6 men), policy-makers in the field of the education "Civil Engineering", aged from 40 to 55.

- Twenty five professors (13 women and 12 men) of the socio-humanitarian disciplines - (philosophy, history, psychology, sociology, law, cultural), aged from 35 to 70

- The six hundred eight graduate students, (326 women and 282 men, aged from 25 to 32.

\section{Results}

The respondents expressed their positions about the social-humanitarian disciplines and thoroughly argued them. The results of this research are presented in the Tabl. 1.

Table1. The socio-humanitarian disciplines in the technical university.

\begin{tabular}{|l|c|c|c|c|c|}
\hline \multirow{2}{*}{ Respondents } & \multirow{2}{*}{$\begin{array}{c}\text { Number of } \\
\text { respondent } \\
\text { s }\end{array}$} & \multicolumn{4}{|c|}{ The social-humanitarian disciplines } \\
\cline { 5 - 6 } & needed & $\begin{array}{c}\text { not } \\
\text { needed }\end{array}$ & $\begin{array}{c}\text { universal } \\
\text { content }\end{array}$ & $\begin{array}{c}\text { focused on the } \\
\text { profession of } \\
\text { students }\end{array}$ \\
\hline The graduate students & 608 & $94.2 \%$ & $5.8 \%$ & $62.3 \%$ & $37.7 \%$ \\
\hline $\begin{array}{l}\text { Professors of the } \\
\text { technical subjects }\end{array}$ & 25 & $76 \%$ & $24 \% 6$ & $12 \%$ & $88 \%$ \\
\hline $\begin{array}{l}\text { Professors of the social } \\
\text { and humanitarian } \\
\text { subjects }\end{array}$ & 25 & $100 \%$ & $0 \%$ & $84 \%$ & $16 \%$ \\
\hline Subtotal & 658 & $94 \%$ & $6 \%$ & $61 \%$ & $39 \%$ \\
\hline
\end{tabular}

As can you see from the tabl.1 the vast majority of respondents (94\%) consider necessary the inclusion the socio-humanitarian disciplines for learning in the technical university

Respondents noted:

- "Modern construction is a complex field of activity, it involved representatives of different professions, different nationalities. So they need to understand the differences between people".

- "The coordination of human resources at all levels: line, middle and senior managers, is a necessary condition for solving the production and organizational problems".

- "Social life is so complicated, that you can't be successful without knowledge of the society life".

- "It is impossible to abandon the humanities knowledge, because it is values, attitudes, interests and everything that makes life unique character".

- "The humanities-educated specialist in solving problems, including purely technical, is able to accept humanitarian (human) informed decisions".

However, there are those who believe that socio-humanitarian disciplines should "withdraw" from the educational process and to add time for a deeper study of the special subjects.

These respondents do not deny the importance of the social-humanitarian disciplines. However, they believe that these disciplines should be examined as optional, or through informal training. Students must participate in cultural life, politics, sports, etc. For 
example, they can participate in the intercultural evenings (programs) as part of campus, where foreign students introduce their classmates with their own culture. When students work in the student construction teams, they master the skills of communication, leadership, managerial competences better than when they are listen a lecture.

The most of the professors (88\%), which make policy in the education in MGSU, believe that all the disciplines should be practice-oriented and take into account the peculiarities of the future profession. In other words, any course (psychology, sociology, law, cultural studies) should be specialized. According to this group of professors, the socio-humanitarian knowledge may become the real basis for the decision in favor of the humanitarian values, if the students will establish a specific bond with their future profession during their studies at The University [22, 23].

The professors of the social and humanitarian subjects do not agree with this point of view. The graduate students in their opinions on this issue were divided. Some of them $(37.7 \%)$ agree that any discipline, including the social and humanities sciences, need to give "binding" to the profession. However, the most of the graduate students $(62,3 \%)$ are in solidarity with the professors of the social-humanitarian disciplines.

Social competence is the universal category; it is testament of the cultural level of man. If all the social-humanitarian discipline will focus only on the professional field, it will narrow their content and even distort it. The next issue is a priority in the study of the social-humanitarian disciplines. What kind of the competences' level the sociohumanitarian disciplines can and should provide?

Recall, the first level is the ontological level (presentation, understanding, awareness, reproduction), the second level is the behavioral level (the application of theories to the solution of standard tasks) and the third level is existential level (values, meanings, positions). This question proved to be difficult for the professors of the special subjects and the graduate students. They compare the socio-humanitarian and the technical disciplines. They compare the socio-humanitarian and the technical disciplines with each other. They fix a lot of differences and they think that it is the disadvantages. However, discussion of these differences is beyond the scope of this article.

The professors of the humanitarian disciplines (philosophy, history, psychology, etc.) believe that they are responsible for the "existential" level.

The purpose of these disciplines is the formation of human values, personal meaning and social position. Therefore, they should not focus on the professional activities. Therefore, they should not focus on the professional activities. These disciplines help to bring awareness of the humanitarian issues, forming the readiness to accept the humanitarian an informed decisions.

The professors of the social disciplines (sociology, law, cultural studies, psychology) are ready to develop practice-oriented courses. For example, "Sociological problems of urban development", "Social interaction in the construction industry", "Psychology of decision making", "Sociology and psychology of conflict", "Psychology of technical creativity" and others. These courses do not only provide a professional reference, but go to the second (behavioral) level, that is, forms of social competence on skill level. These training courses can shape the social competence at the level of the skills [24].

\section{Conclusion}

The social and humanitarian disciplines are a necessary condition of the professional formation of the person. Their presence at the technical university is mandatory. It is a recognized all the participants of the educational process. However, these disciplines require a special approach. Certainly, the subjects should reflect specificity of professional activity, but not at the expense of narrowing of the fundamental humanities, such as the 
philosophy or the history. They perform their functions; form the human values, personal meanings and citizenship. Social sciences as individual courses can have a professional reference in and out on the behavioral level can take into account the professional sphere; they help to create social awareness on the skill level.

\section{References}

1. R.E. Boyatzis, The competent manager: a model for effective performance (New York, 1982)

2. L.M. Spencer, S.M. Spencer, Competence at Work: Models for Superior Performance (John Wiley \& Sons, Inc. 1993)

3. R.H. Rosier (ed.), The competency model handbook: V. 1-4, (Lexington, MA: Linkage 1994-1997)

4. R.E. Boyatzis, D. Leonard, K. Rhee, J.V. Wheeler, Competencies can be developed, but not the way we thought. Capability, 2(2), 25-41 (1996)

5. W. Hutmacher, Key Competencies for Europe. Report of the Symposium (Berne, Switzerland, March 27-30, 1996). (CDCC). Strasburg. (1997)

6. M.A. Hubble, B.L. Duncan, S.D. Miller, American Psychological Association, Washington, DC (1999)

7. J. Raven, Competence in modern society: the identification, development and implementation, translated from English, "Cogito Center", Moscow, 396 (2002)

8. B. Oscarsson, Basic Skills as a Compulsory Component of High-quality Vocational Education, Evaluation of the quality of vocational education: Report 5, European Training Foundation. Tacis DELPHI project, Moscow, (2001)

9. I.V. Wagner, Tomsk State Pedagogical University Bulletin, 13, 189-191, (2011)

10. X. Sanchez Vila, Inquiries into European higher education in civil engineering: SOCRATES-ERASMUS Thematic Network Project: European civil engineering education and training, Sixth EUCEET 7 (2006)

11. R.E. Boyatzis, A. Murphy, J. Wheeler, Psychological Reports, 86, 47-64 (2000)

12. R.E. Boyatzis, F. Sala, Assessing Emotional Intelligence Competencies, Hauppauge, NY: Nova Science Publishers (2004)

13. R.E. Boyatzis, Journal of Management Development, 27(1), 5-12·(2008)

14. R.E. Boyatzis, Journal of Management Development, 25, 7, 607-23 (2006)

15. R.E. Boyatzis, L. Stubbs, S. Taylor, Academy of Management Journal on Learning and Education, 1, 2, 150-62 (2002)

16. N.G. Miloradova, MSUCE Bulletin, 2, 62-64. (2007)

17. E.A. Shnyrenkov, I.P. Pryadko, Procedia Engineering, 117, 325-330 (2015)

18. A.D. Ishkov, N.G. Miloradova, A.Yu. Chernyshev, Procedia - social and behavioral sciences, 171, 765-770 (2015)

19. M.G. Leontev, Social and Behavioral Sciences, 142, 695-701 (2014)

20. Z.I. Ivanova, O.V. Yudenkova, Asian Social Science, 11, 1; 297-303 (2015)

21. Z.I. Ivanova, O.V. Yudenkova, Middle-East Journal of Scientific Research, 16 (8), 1084-1087, (2013)

22. E. Khripko Matec web of conferences, 73, 07021 (2016)

23. N.G. Miloradova, A.D. Ishkov, Procedia Engineering. 117. 246-251 (2015) 
24. E.A. Shnyrenkov, E.V. Romanova, Procedia Engineering, 117, 336-341 (2015) 